\title{
Bcl-2-regulated cell death signalling in the prevention of autoimmunity
}

\author{
D Tischner ${ }^{1}$, C Woess ${ }^{1}$, E Ottina ${ }^{1}$ and A Villunger ${ }^{*, 1}$
}

Cell death mediated through the intrinsic, Bcl-2-regulated mitochondrial apoptosis signalling pathway is critical for lymphocyte development and the establishment of central and maintenance of peripheral tolerance. Defects in Bcl-2-regulated cell death signalling have been reported to cause or correlate with autoimmunity in mice and men. This review focuses on the role of Bcl-2 family proteins implicated in the development of autoimmune disorders and their potential as targets for therapeutic intervention.

Cell Death and Disease (2010) 1, e48; doi:10.1038/cddis.2010.27; published online 3 June 2010

Subject Category: Immunity

\section{Apoptotic Cell Death and Autoimmune Disease}

Apoptosis is conserved among all metazoans and in vertebrates two main signalling pathways converge at the level of shared cysteine-dependant aspartic acid-specific proteases, known as caspases, that execute cell death by the cleavage of vital cellular substrates. ${ }^{1}$

The 'extrinsic' pathway to apoptotic cell death is initiated by the ligation of so-called death receptors (DRs) on the cell surface of a target cell with the specific 'death ligand' on an opposing (immune) cell, which triggers the formation of the death-inducing signalling complex (DISC). The tumor necrosis factor (TNF) family members TNF, Fas ligand (FasL/ CD95L) and TNF-related apoptosis-inducing ligand (TRAIL) can prompt apoptosis of immune but also non-immune cells through their cognate TNF-family receptors $(R)$, TNF-R1, Fas/APO1/CD95, TRAIL-RI/DR4 and TRAIL-RII/D5, the only TRAIL-R found in mice. ${ }^{2}$ Multimerization of trimeric receptors leads to direct or indirect recruitment of the adaptor protein FADD allowing for engagement and activation of initiator pro-caspase 8 or in humans also pro-caspase 10 molecules into the DISC and subsequent activation of effector caspases 3,6 and $7 .^{2,3}$ The importance of this cell death pathway that co-evolved in vertebrates with the ability to launch an adoptive immune response, for the suppression of autoimmunity is exemplified in Fas-deficient $\mathrm{Ipr}^{4}$ and FasL-deficient gld mice ${ }^{5}$ and in patients suffering from autoimmune lymphoproliferative syndrome (ALPS) that can present with a variety of different pathologies and harbor mutations either in Fas, FasL or caspase-8/10 genes, respectively. ${ }^{6}$ It is noteworthy that here, depending on context and cell type, the outcome of DR-ligation is not always cell death, but can also result in activation of the NF-kB signalling pathway and subsequent cell survival, migration or cytokine release. $^{3}$

The 'intrinsic' apoptotic pathway is induced in response to numerous stimuli, including DNA damage, endoplasmatic reticulum (ER)-stress, cytokine-deprivation or high-affinity ligation of antigen receptors, ${ }^{7}$ leading to mitochondrial outer membrane permeabilization (MOMP) that enables the release of apoptogenic factors from the inner-membrane space, most importantly cytochrome $\mathrm{C}$, triggering oligomerization of the adapter molecule Apaf-1, leading to recruitment and activation of initiator pro-caspase 9 molecules. Subsequent cleavage-dependent activation of effector caspases leads to cellular demise. ${ }^{7}$

MOMP is regulated by the complex interplay of individual members of the Bcl-2 family that can be divided according to their function in two subgroups. The anti-apoptotic Bcl-2 family members, Bcl-2, Bcl- $x_{L}, B c l-w, M c l-1$ and $B f l-1 / A 1$ contain up to four Bcl-2-homology $(\mathrm{BH})$-domains and localize mainly to intracellular membranes such as ER and mitochondria. The pro-apoptotic members can be further subdivided in Bax/Bak-like proteins (Bax, Bak and Bok), containing three $\mathrm{BH}$-homology regions and the 'BH3-only' proteins, including Bad, Bid, Bim, Bmf or Puma that contain only one such homology domain. MOMP requires the pore-forming capacity of Bax and/or Bak that act genetically downstream of

\footnotetext{
${ }^{1}$ Division of Developmental Immunology, BIOCENTER, Medical University Innsbruck, Innsbruck, Austria

${ }^{*}$ Corresponding author: A Villunger, Division of Developmental Immunology, BIOCENTER, University of Innsbruck, Fritz-Pregl-Str.3, Innsbruck A-6020, Austria. Tel: + 435129003 70380; Fax: + 435129003 73960; E-mail: andreas.villunger@i-med.ac.at

Keywords: apoptosis; Bcl-2 family; BH3-only proteins; autoimmunity

Abbreviations: Bad, Bcl-2 antagonist of cell death; Bak, Bcl-2 antagonist/killer; Bax, Bcl-2 associated protein X; Bcl-X, Bcl-2 related protein X; Bcl-2, B cell lymphoma 2; $\mathrm{BH}, \mathrm{Bcl}-2$ homology domain; Bbc3, Bcl-2 binding component 3; Bid, Bcl-2 interacting domain death agonist; Bik, Bcl-2 interacting killer-like; Bim, Bcl-2 interacting mediator of cell death; Blk, Bik-like; Bmf, Bcl-2 modifying factor; PUMA, p53-upregulated modulator of apoptosis; Mcl-1, myeloid cell leukemia-1; APC, antigen presenting cell; BCR, B cell receptor; BAFF, B cell activating factor of the TNF family; FLIP, FLICE-like inhibitory protein; NF- $\kappa B$, nuclear factor 'kappa-light-chainenhancer' of activated B-cells; HSA, heat stable antigen; TCR, T cell receptor; MHC, Major histocompatibility complex, ; DN, double negative; DP, double positive; SP, single positive

Received 09.4.10; revised 28.4.10; accepted 28.4.10; Edited by H-U Simon
} 
BH3-only proteins. ${ }^{8}$ Activation of Bax and Bak may either involve their release from sequestration by pro-survival $\mathrm{Bcl}-2$ homologues, because of competitive binding of $\mathrm{BH} 3-$ only proteins, or their direct interaction with a subset of $\mathrm{BH} 3-$ only proteins, that is, Bim, truncated (t)Bid and possibly also Puma. It is noteworthy that the intrinsic cell death pathway can connect to the DR pathway through caspase-8-mediated processing of the BH3-only protein Bid. ${ }^{9,10}$

In general, apoptotic cell death under steady-state conditions is poorly immunogenic because of the fast resolution of dying cells by macrophages. Defects in the clearance of apoptotic cells and subsequent secondary necrosis or impaired degradation of their cellular contents by phagocytes, for example because of loss of or reduced function of engulfment genes such as MFG-8, complement factor C1q or the lysosomal DNA-degrading enzyme, DNAasell, leads to the development of autoimmune disease in mice and men. These observations highlight the relevance of efficient corpse clearance and cell content degradation by phagocytes for the maintenance of tolerance (for detailed review, see Nagata et al. ${ }^{11}$ ).

\section{The Bcl-2 Family Proteins as Barrier against Autoimmune Disease}

Although no loss of function mutations in $\mathrm{BH} 3-$ only proteins have been reported in patients suffering from autoimmune diseases, overexpression of the prosurvival family members $\mathrm{Bcl}-2,{ }^{12} \mathrm{Mcl}-1^{13}$ and $\mathrm{Bfl}-1 / \mathrm{A} 1^{14,15}$ have been noted in patients suffering from systemic lupus erythematosus (SLE), although not all these observations could be confirmed independently. ${ }^{16}$ It is noteworthy that reduced levels of Bim, because of an activating mutation in NRAS leading to accelerated proteasomal degradation of this $\mathrm{BH}$-only protein was associated with ALPS in one patient in which the Fassignalling pathway is still intact. ${ }^{17}$ Furthermore, autoimmune disease-associated cytokines such as IL-17 or BAFF seem to modulate the expression levels of pro-survival $\mathrm{Bcl}-2$ family proteins, including $\mathrm{Bcl}-2^{18}$ and Bfl-1/A1 in SLE-patients, ${ }^{14}$ supporting the notion that impairment of the Bcl-2-regulated apoptosis pathway can contribute to the rise of autoimmunity in men. It is noteworthy that in the murine model for type I diabetes mellitus, NOD (non-obese diabetic), thymocytes fail to upregulate Bim on activation with high-avidity auto-antigen, leading to impaired apoptosis in potentially auto-reactive cells in these animals. ${ }^{19}$ Consistently, loss of Bim or overexpression of $\mathrm{Bcl}-2$ in mice triggers SLE-like disease leading to premature lethality. ${ }^{20-22}$

\section{Bcl-2-Regulated Cell Death Enforces Central Tolerance}

Central tolerance mechanisms enforced during early T-cell development in the thymus ensure that only positively selected T-cell precursors can leave for the periphery when expressing a functional TCR that has a 'below-threshold' affinity for self-peptide/MHC complexes (Figure 1). In contrast, thymocytes that lack a functional (pre)TCR die by neglect, whereas those expressing an 'above-threshold' highaffinity TCR die by apoptosis during negative selection, both processes regulated to a large extent by induction of different
Bcl-2 pro-survival proteins, for example, $A 1$ and/or their interaction with $\mathrm{Bim}, \mathrm{Mcl}-1$ or $\mathrm{Bcl}-\mathrm{x}^{7}$ Loss of the $\mathrm{BH} 3-$ only Bim rescues double-positive (DP) thymocytes from TCR/CD3 ligation-induced apoptosis in vitro and in vivo, a phenomenon also observed in mice overexpressing $\mathrm{Bcl}-2^{23}$ or that lack Bax and Bak in the T-cell lineage. ${ }^{24}$ Furthermore, bim $^{-/-}$ thymocytes are resistant to Staphylococcus enterotoxin $B$ (SEB)-superantigen-induced deletion in fetal thymic organ culture and resist negative selection in different TCRtransgenic mouse models. For example, in transgenic mice expressing $\alpha \beta$ TCRs specific for the male HY MHC-class I restricted antigen, double-positive thymocytes are deleted in male but positively selected in female mice. However, in the absence of Bim, thymocytes in male mice were rescued from negative selection. In addition, loss of Bim protected OT-II TCR-transgenic thymocytes from OVA (Ovalbumin)mediated cell death. ${ }^{25}$ Since negative selection can still occur at a later stage of thymocyte development at the corticalmedullary junction of the thymus, semi-mature $\mathrm{CD}^{+}{ }^{+}$single positive, heat-stable antigen positive $(\mathrm{HSA}+)$ thymocytes derived from Bim-deficient or vav-bcl-2 transgenic mice were analyzed in more detail and compared with thymocytes derived from Fas-deficient Ipr mice or mice expressing a dominant-negative mutant of FADD, blocking all DR-mediated apoptosis. These studies confirmed again a critical role for Bim in negative selection while DR signalling appeared dispensable. ${ }^{26}$ Along the line, studies implicating TRAIL in negative selection still await confirmation. ${ }^{27-29}$ Thus, loss of bim or failure in Bim-induction should contribute to the development and escape of auto-reactive $\mathrm{T}$ lymphocytes, but once backcrossed onto the C57BL/6 genetic background the autoimmune pathology originally described is strongly ameliorated. $^{20,30}$ One possible explanation for this conundrum was suggested in a publication that shows that Bimdeficiency in the hematopoietic systems renders mice on the C57BL/6 background resistant to myelin oligodendrocyte glycoprotein (MOG)-induced experimental autoimmune encephalomyelitis and streptozotocin-induced diabetes. ${ }^{31}$ This phenomenon was associated with an impaired ability to activate Bim-deficient T cells through their TCR, suggested to be due to reduced calcium release and dephosphorylation of nuclear factor of activated T cells, culminating in reduced cytokine production. Impaired calcium release associated with increased levels of inhibitory complexes consisting of $\mathrm{Bcl}-2$ and the inositol triphosphate receptor $\left(\mathrm{IP}_{3} \mathrm{R}\right)$, located at the ER. ${ }^{31}$ Interaction of Bcl-2 family proteins with the $I P_{3} R$ have been reported previously and have been associated with deregulated T-cell apoptosis (reviewed in Rong and Distelhorst ${ }^{32}$ ). In the absence of Bim (or Bax/Bak), more Bcl-2 may be available to bind $I P_{3} R$ at the $E R$, thereby reducing calcium release and $\mathrm{T}$-cell activation in response to selfantigens, or antigens in general, but this concept awaits independent confirmation. It is noteworthy that self-reactive $\mathrm{T}$ cells specific for myelin basic protein or MOG seem to be present in comparable number in wt and $\mathrm{bim}^{-1-}$ mice, whereas insulin-reactive T-cell clones seem to be reduced. ${ }^{31}$ However, because of the observed impaired reactivity of Bimdeficient $T$ cells, it is hard to judge if such auto-reactive cells can be activated effectively by auto-antigen stimulation in vitro and may actually still be present in increased numbers. 


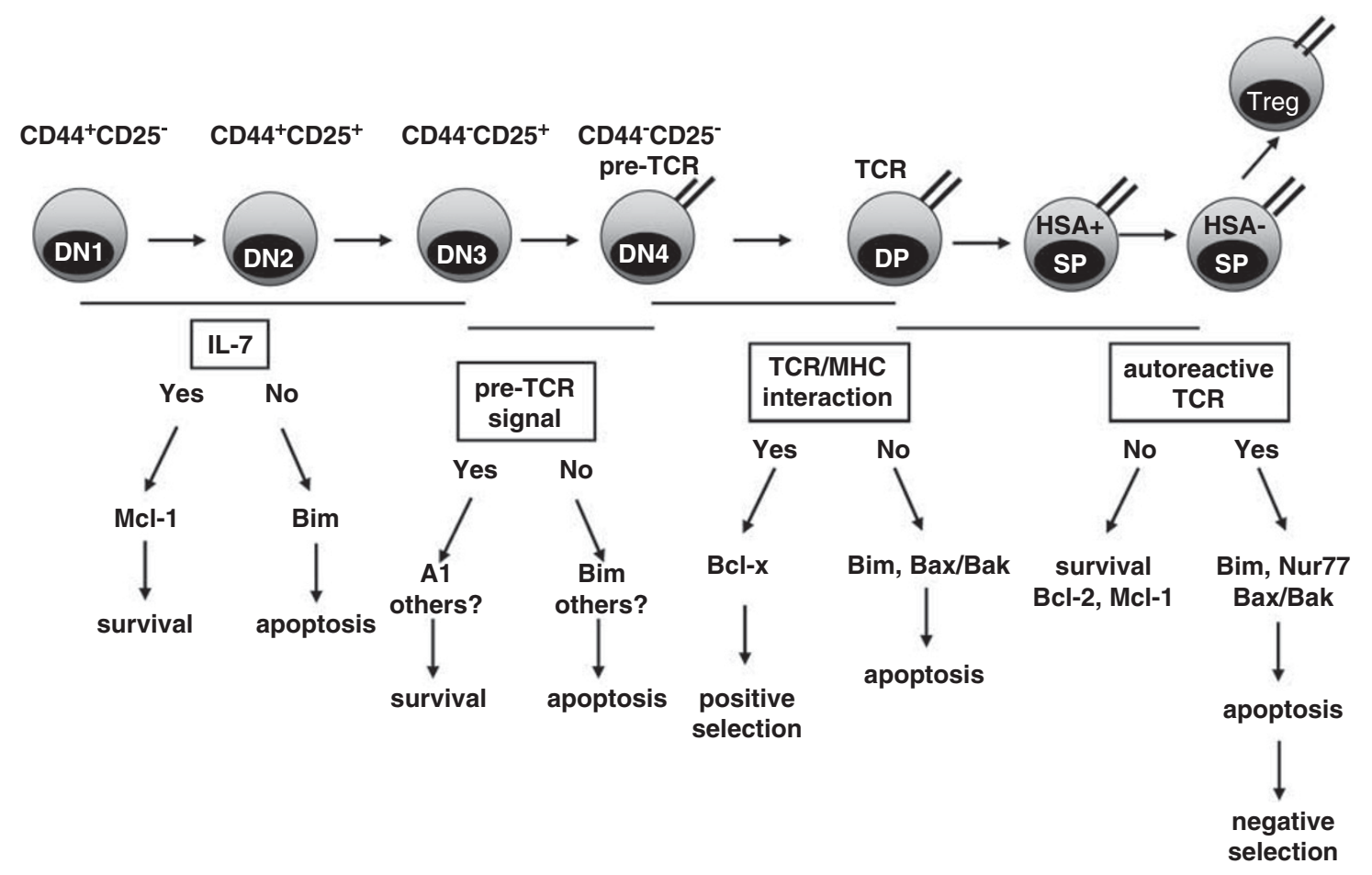

Figure 1 Selection processes during T-cell development. Apoptosis contributes to the development of functional T cells various stages during T-cell development. During early stages in the thymus cells are subjected to positive and negative selection processes. In the double-negative stage 3 the TCR $\beta$ chain locus is rearranged. A functional preTCR secures survival and allows expansion and transition to the double-positive stage in which the TCR $\alpha$ chain locus is rearranged. In case of TCR expression on the cell surface, DP thymocytes interact with MHC-self-peptide complexes and can receive survival signals (positive selection). In contrast, when TCR rearrangement fails or thymocytes receive a 'below-threshold' TCR signal they die by apoptosis, termed death by neglect. Negative selection assures that DP or SP ${ }^{+} \mathrm{HSA}^{-}$thymocytes expressing an auto-reactive TCR, transmitting 'above-threshold' signals are eliminated. This process is mediated by induction of Bim and the nuclear orphan receptor Nur77. Bcl-2 family proteins critically involved in these processes are indicated. Abbreviations: TCR, T-cell receptor; MHC, major histocompatibility complex; DN, double negative; DP, double positive; SP, single positive; HSA, heat stable antigen

However, based on these observations it also seems feasible that negative selection can effectively happen in the absence of Bim, as supported by recent observations using a modified transgenic mouse model, HY-TCR ${ }^{\mathrm{cd} 4}$, in which expression of the auto-antigen-specific TCR is timed to the $\mathrm{CD} 4{ }^{+} 8^{+}$stage of thymocyte development, resembling more the physiological situation than the classical HY-transgenic mouse model. Using this model system, it was shown that apoptosis of self-reactive DP-thymocytes was Bim-dependent in $\mathrm{HY}^{\mathrm{cd} 4}$ bim $^{-1-}$ male mice but these animals failed to accumulate mature $\mathrm{CD}^{+}$thymocytes specific for the auto-antigen, indicative for successful negative selection and establishment of tolerance in the absence of Bim. ${ }^{33}$ Furthermore, experiments revealed that MMTV superantigenmediated deletion of thymocytes in $\mathrm{H} 2 \mathrm{~K}$ mice is only marginally impaired in the absence of Bim. ${ }^{34}$ These observations are in line with observations made in recombination-dependent Rec-HY transgenic mice in which, again, expression of the auto-reactive TCR is timed to the onset of $\operatorname{TCR} \alpha$ chain rearrangement. ${ }^{35}$ In this model system, self-reactive thymocytes showed a CD $4{ }^{\mathrm{lo}} \mathrm{CD} 8{ }^{\mathrm{lo}}$-activated phenotype and loss of Bim impaired apoptosis of these cells but failed to rescue their differentiation. It is noteworthy that these cells upregulated the nuclear orphan receptor Nur77 and were ultimately deleted in a Bim-independent manner. ${ }^{35}$

Nur77 has been implicated in thymocyte apoptosis and negative selection based on studies using mice overexpres- sing a dominant-negative version of this orphan nuclear receptor and the observation that Nur77 induction was also found impaired in NOD mice. ${ }^{36}$ However, Nur $77^{-1}$ mice showed no defects in negative selection but this discrepancy was ascribed to the fact that the dominant-negative protein also blocks the function of related Nor-1 and Nurr1 that may compensate for the absence of Nur77. ${ }^{36}$ Most recently, a unifying model for negative selection was suggested, based on the observation that on stimulation of DP thymocytes from lck-Bcl-2 transgenic mice with PMA and ionomycine, Nur77 and Nor-1 can translocate from the nucleus to the mitochondria, associate with Bcl-2 and expose its BH3-only domain, converting it into a pro-apoptotic molecule. ${ }^{37,38}$ Consistently, exposure of the Bcl-2/BH3-domain was also observed in thymocytes prone to undergo negative selection in the $\mathrm{F} 5$ and HY-TCR transgenic mouse models. These findings were also used as an explanation as to why negative selection is not impaired in Bcl-2 transgenic mice, but clearly affected in bim $^{-1-}$ mice. $^{25}$ Thus, it seems that Bim and Nur77, by inhibition or conversion of $\mathrm{Bcl}-2$, are two pro-apoptotic effectors that converge at the mitochondria to mediate negative selection (Figures 2 and 3), but this leaves us with an unresolved conundrum. Why do $\mathrm{bim}^{-1-} \mathrm{bcl}-2^{-1-}$ mice fail to develop autoimmune disease? Bcl-2-deficient mice that lack a single allele of Bim are effectively rescued from polycystic kidney disease and lymphopenia caused by loss of Bcl-2. Loss of both alleles of bim over bcl-2 even leads to increased 


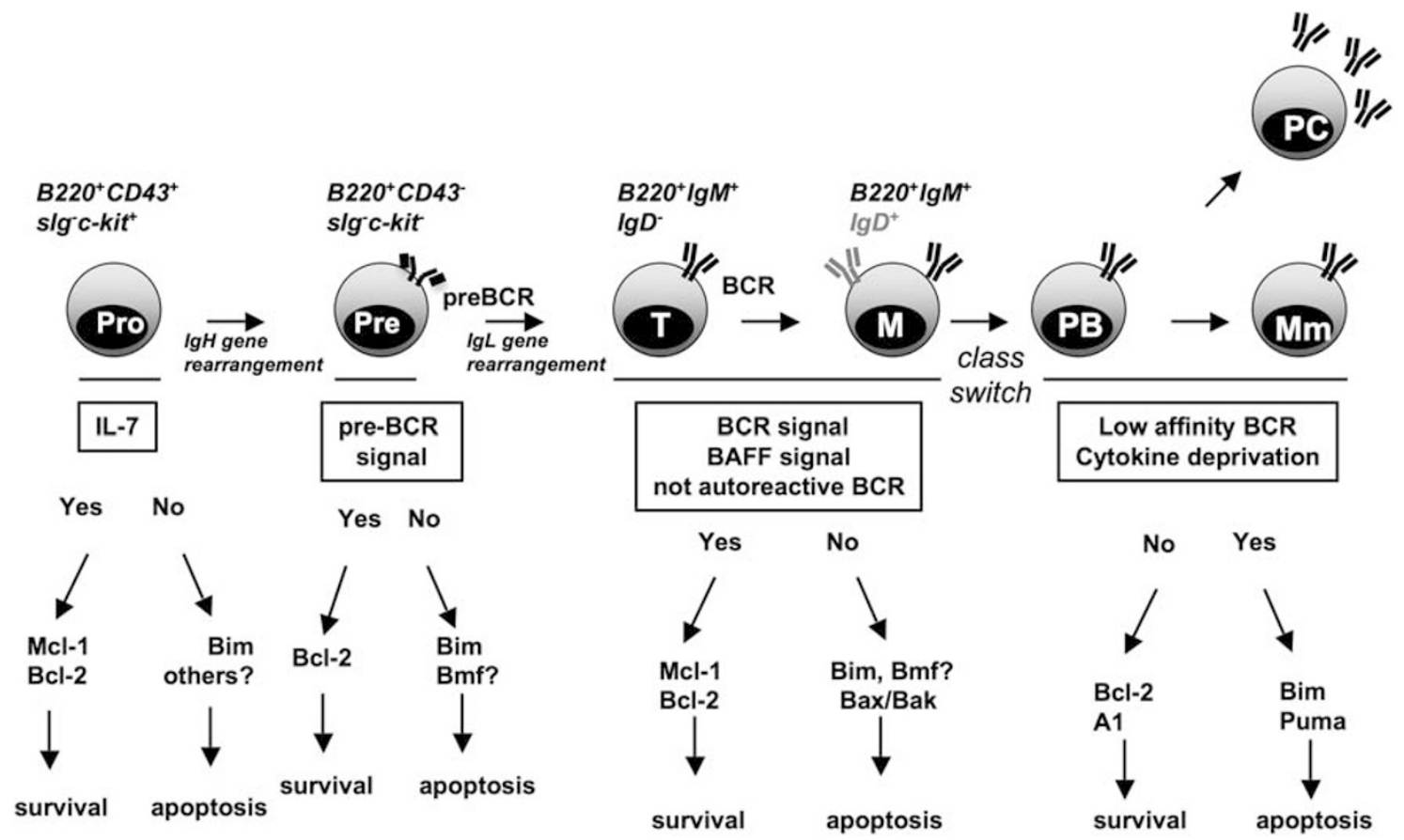

Figure 2 Selection processes during B-cell development. To secure survival of functional B cells, progenitors are subjected to stringent selection in the bone marrow, but also later in the periphery. Rearrangement of the immunoglobulin $(\mathrm{lg})$ heavy $(\mathrm{H})$ gene locus in during pro/pre-B-cell transition secures survival and expansion of cells that express a functional preBCR on the cell surface, while others die by neglect. Late stage preB cells start to rearrange their Ig light (L) gene loci. IgM expressing immature transitional $B$ cells are subjected to negative selection in the bone marrow before finishing their maturation in the spleen. There, $B$ cells are again screened for autoreactivity, for example, arising during germinal center reactions, and can be eliminated. Alternatively, they can mature into Ig-secreting plasma cells or memory B cells. Bcl-2 family proteins critically involved in these processes are indicated in the appropriate locations. Abbreviations: BCR, B cell receptor; $\mathrm{T}$, transitional; M, mature; Mm, memory cell B cells; PB, plasmablast; PC, plasma cell

leukocyte numbers when compared with wt mice, ${ }^{30,39}$ but these cells do not seem to be auto-reactive, as evidence by the lack of obvious autoimmune pathology in these mice (P Bouillet, pers. communication). It remains possible that peripheral tolerance mechanisms keep such auto-reactive cells in check in these animals or, alternatively, that Nur77 may also convert other prosurvival Bcl-2 homologues into killers, but the 'conversionconcept' still awaits independent confirmation. Therefore, Nur77's ability to contribute negative selection may still mainly lie in its proven ability to regulate gene expression. ${ }^{40,41}$ However, it cannot be excluded at present that negative selection may also involve additional undefined pro-apoptotic proteins or alternative cell death mechanisms.

Development and negative selection of B cells occurs in the bone marrow as well as in the periphery (Figure 2) and a first check point seems to be imposed at the preB to immature B-cell transition in which many B-cell progenitors with an autoor poly-reactive pre-B BCR are cleared but found to persist in patients with SLE or rheumatoid arthritis. ${ }^{42}$ Auto-reactivity can also be avoided by receptor editing but most immature B cells formed in the bone marrow are destined to die there. B-cell precursors that manage to rearrange their BCR properly are subjected to negative selection at the so-called transitional T1 stage of B-cell development (Figures 2 and 3), before leaving for the periphery to complete maturation in the spleen, but are still susceptible to negative selection processes. ${ }^{42}$ BCR ligationinduced apoptosis in the T1 B-cell model cell line WEHI-231, commonly used to study negative B-cell selection can be blocked effectively by overexpression of $\mathrm{Bcl}-\mathrm{x}_{\mathrm{L}}{ }^{43}$ or related
$\mathrm{Bfl}-1 / \mathrm{A} 1{ }^{44}$ Transgenic expression of $\mathrm{Bcl}-2$ in hematopoietic cells rescues immature and mature $B$ cells from BCR ligationinduced apoptosis ${ }^{45}$ and neutralization of Bcl-2 by Bim seems critical for IgM-induced killing of B cells. ${ }^{46}$ Consistently, loss of Bim rescues immature anti-hen-egg-lysozyme (HEL) Ig transgenic $B$ cells in the bone marrow from deletion in membranebound $(m) H E L$ transgenic recipient mice. In spite of the strong evidence for Bim as a critical regulator of central B-cell tolerance not all self-reactive $B$ cells were spared from death in this model system in its absence, suggesting that Bim-independent mechanisms can contribute to B-cell deletion in the bone marrow. ${ }^{46}$ Although non-cell death-related mechanisms, such as anergy or proliferation deficits may account for this effect, we speculate that other $\mathrm{BH} 3-$ only proteins, most likely Bmf, may contribute to B-cell selection, since we observed B-cell restricted lymphadenopathy ${ }^{47}$ and reduced sensitivity to IgMinduced apoptosis in selected B-cell subsets in $\mathrm{bmf}^{-/}$mice ( $A \mathrm{~V}$, unpublished). Our speculation is supported by the fact that $\mathrm{B}$-cell restricted loss of both Bax and Bak protects $B$ cells more potently from IgM-induced killing than loss of Bim and causes rapid onset of autoimmune disease in these mice. ${ }^{48}$ Although animals lacking both Bim and Puma do also show an accumulation of mature B cells, IgM-mediated killing of B cells seemed entirely Bim-dependent in these double-deficient animals, excluding Puma as a putative effector during B-cell selection. ${ }^{49}$ Consistently, bim ${ }^{-/-}$puma $^{-/-}$mice fail to develop signs of autoimmune pathology that exceed those noted in Bimdeficient animals but show an increased incidence of spontaneously arising diffuse large B-cell lymphomas. ${ }^{49}$ 

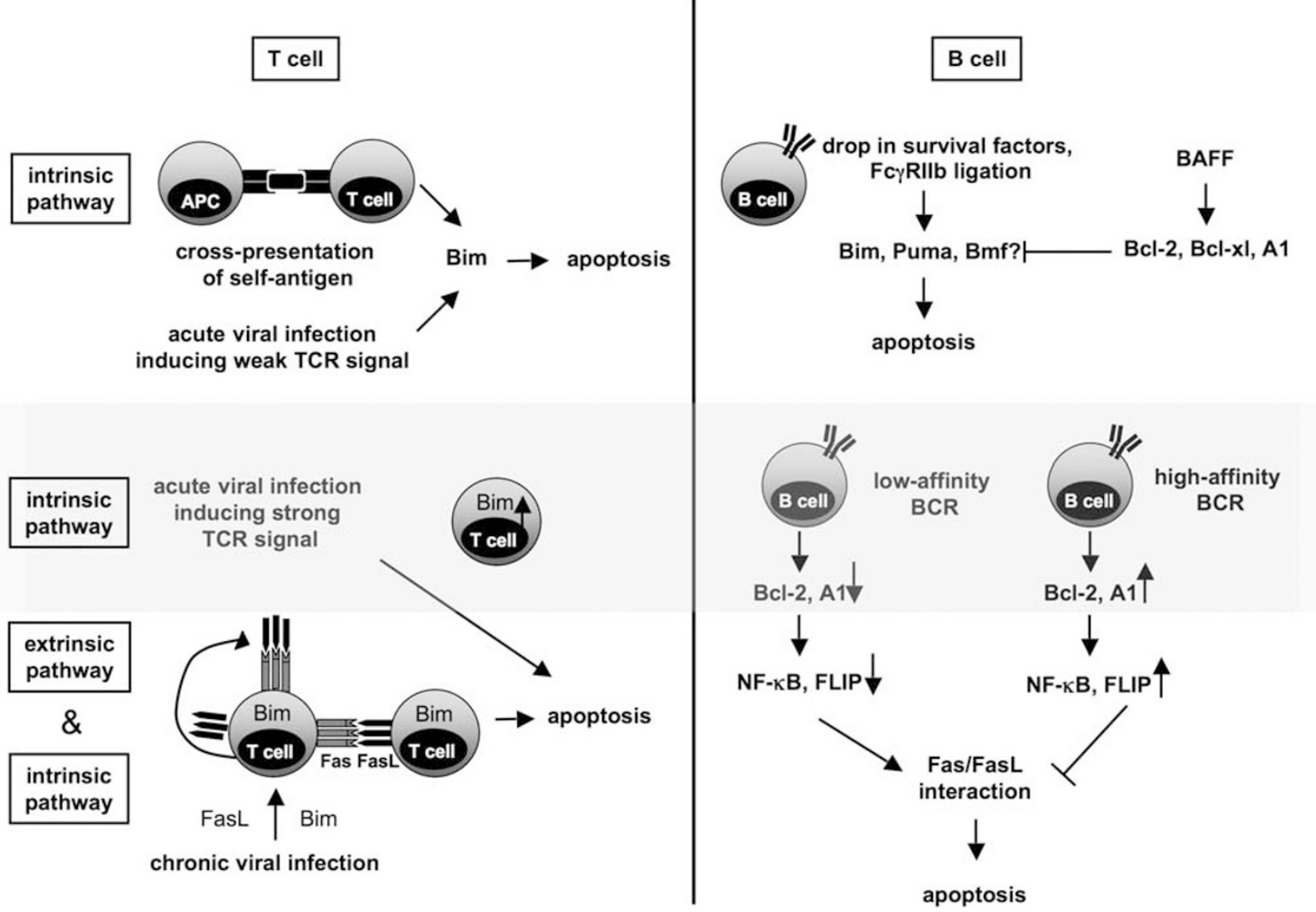

Figure 3 Regulation of peripheral tolerance by the intrinsic and extrinsic apoptosis pathways in $\mathrm{T}$ and B cells. Both apoptosis pathways cooperate to eliminate no longer functional or required activated T and B lymphocytes in peripheral lymphoid organs. Under non-inflammatory conditions T cells recognizing self-antigen presented by APCs undergo apoptosis after cross-presentation that is mediated by the intrinsic apoptosis pathway by induction of the BH3-only protein Bim. In contrast, when acute viral infections induce strong TCR signals or when they are becoming chronic the extrinsic pathway by Fas-FasL interaction (either in an autocrine or paracrine manner) is required for elimination of activated T cells. The intrinsic pathway contributes to the termination of both, acute as well as chronic immune response because of activation on cytokinedeprivation. During affinity maturation in germinal centers, the intrinsic and extrinsic pathway cooperate to select B lymphocytes expressing high-affinity BCRs. In B-cell clones that receive insufficient stimulation by their low-affinity BCR, anti-apoptotic Bcl-2 protein family members (e.g., Bcl-2, A1) drop. This response is accompanied by a reduced level of NF- $\kappa$ B activation leading to reduced FLIP-levels, in the absence of CD40 signals, making them more susceptible to Fas/FasL-induced apoptosis. In contrast, ligation of high-affinity BCRs increases the amount of pro-survival molecules of the Bcl-2 family, as well as NF- $\kappa$ B and FLIP, resulting in increased resistance to cell death. After elimination of the pathogen, a drop of survival factors or FcyR Rlb ligation can activate BH3-only proteins such as Bim and maybe Puma and Bmf to secure clearance of plasma cells. This can be counteracted by cytokines such as BAFF that lead to up-regulation of anti-apoptotic Bcl-2 family proteins like Bcl-2, Bcl- $x_{L}$ and A1. Abbreviations: APC, antigen presenting cell; BCR, B-cell receptor; BAFF, B-cell activating factor of the TNF family; NF-kB, nuclear factor 'kappa-light-chain-enhancer' of activated B cells; FLIP, FLICE-like inhibitory protein

In summary, whereas the contribution of the extrinsic pathway for the establishment of central tolerance remains controversial, the intrinsic Bcl-2-regulated apoptosis pathway is clearly pivotal for this process. Bim seems the key player in this event and so far little experimental evidence exists that other members of the $\mathrm{BH} 3$-only subgroup, although clearly co-regulating lymphocyte homeostasis together with $\mathrm{Bim},{ }^{49,50}$ can contribute to negative selection during the establishment of central tolerance.

\section{Maintenance of Peripheral Tolerance by Apoptotic Cell Death}

In spite of the stringency of negative selection, some autoreactive $T$ cells can escape into the periphery and low-affinity interactions between auto-antigens and antigen-receptors may actually contribute to lymphocyte survival. ${ }^{42}$ Escapees of central tolerance mechanisms may be kept in check by the induction of anergy, receptor editing and/or regulatory T (Treg). However, such cells can become activated by pathogenic epitopes with high similarity to peripheral autoantigens, for example, during chronic infection and inflammation. After traumatic injury, increased cell death rates in affected tissues can result in insufficient uptake of necrotic cells, thereby facilitating the release/exposure of self-antigens, such as nuclear proteins or ribonucleic acids. Similarly, continuous exposure to environmental factors or prolonged drug-treatment can lead to the generation of 'neo-selfepitopes' that can activate auto-reactive lymphocytes.

One possibility to eliminate peripheral auto-reactive T cells is mediated by cross-presentation of self-antigens by APCs in secondary lymphoid organs. Under non-inflammatory conditions potentially auto-reactive $T$ cells recognize self-antigen 
presented by DCs, are stimulated to proliferate but then undergo apoptosis. Proteins of the Bcl-2 family are crucial for the induction of cross-presentation initiated cell death because in a model of self-tolerance in which OVA was expressed selectively in pancreatic -cells, overexpression of $\mathrm{Bcl}-2$ or loss of Bim prevented deletion of $\mathrm{CD} 8^{+}$OVA-reactive $\mathrm{T}$ cells, implicating a role of both in mediating crosstolerance. $^{51}$ Consistently, loss of Bim also rescued DO11 $\mathrm{TCR}^{+} \mathrm{CD}^{+}{ }^{+} \mathrm{T}$ cells from deletion on transfer into sOVA transgenic recipients, but surviving $\mathrm{bim}^{-1-} \mathrm{T}$ cells were rendered anergic, questioning the relevance of apoptotic cell death as a unique mechanism for the establishment of peripheral tolerance to systemic self-antigens. ${ }^{52}$

After pathogens have been successfully eliminated by the immune system most effector cells are removed by induction of apoptosis whereas only few differentiate into memory cells. This deletion process is crucial for maintaining lymphocyte homeostasis and the prevention of autoimmunity, for example, by limiting production of inflammatory cytokines. Both, the intrinsic and extrinsic apoptosis pathways were controversially discussed to regulate the shutdown of immune responses but the relative importance of each signalling pathway seems to rely on the type of antigen encountered. ${ }^{53}$

\section{Control of Peripheral T-Cell Tolerance - Lessons from Bim-Deficient Ipr Mice}

In response to antigens that trigger an acute $\mathrm{T}$-cell response, for example, herpes-simplex-virus type 1 (HSV-1) or superantigens such as SEB, depletion of activated $T$ cells in the termination phase of the immune response is blocked by overexpression of $\mathrm{Bcl}-2$ and requires $\mathrm{Bim},{ }^{53,54}$ and in some settings Puma, ${ }^{55}$ upstream of Bax and Bak. In spite of the initial reports involving the Fas/FasL system in this event, numerous studies have shown that DR signalling is dispensable for this process (reviewed in Strasser et al. $^{3}$ and Pellegrini et al. ${ }^{53}$ ). This, however, contrasted the fact that Fas-deficient Ipr and FasL-deficient gld mice develop overt autoimmunity characterized by the appearance of abnormal $\mathrm{CD}^{-} \mathrm{CD}^{-} \alpha \beta \mathrm{TCR}^{+} \mathrm{B} 220^{+} \mathrm{T}$ cells that seem to be derived from persisting effector $T$ cells that downregulated their surface marker expression. ${ }^{3}$ As mentioned, autoimmunity in humans can be directly linked to mutations in components of the Fas/FasL/caspase-8 axis in ALPS patients that can be classified according to genotype as type la, Ib and II, corresponding to germline mutations in Fas, FasL and caspase-8 or 10 , respectively. ${ }^{6}$ However, reduced levels of Bim protein have been reported to account for autoimmunity in an ALPS patient that did not show defects in Fas signalling (ALPS type III). An activating NRAS mutation, resulting in enhanced ERK signalling and a marked reduction in Bim, was identified as the underlying molecular mechanism, leading to the elevated numbers of TCR $\alpha \beta \mathrm{CD}^{-}{ }^{-}{ }^{-}$T cells and chronic lymphoid accumulation. ${ }^{17}$ Thus, disturbances in the intrinsic as well as extrinsic pathway may enforce the development of autoimmunity because of ineffective elimination of effector lymphocytes during the shutdown of immune responses, a notion already suggested in early studies on $\mathrm{Ipr}$ mice expressing transgenic Bcl-2. ${ }^{56}$ How do both pathways contribute to the induction of apoptosis in activated lymphocytes after successful removal of pathogens? One simple explanation might be that upon clearance of the antigen production of pro-survival cytokines ceases, resulting in the Bcl-2-regulated death of activated lymphocytes. Cytokinedeprivation-induced cell death is mediated by Bim and Puma, ${ }^{57}$ but not by the extrinsic pathway. ${ }^{3,53}$ This, however, fails to explain the increased number of lymphocytes as well as the development of autoimmunity in mice and humans suffering from ALPS type I or II. More recent studies indicate that both pathways contribute and cooperate to shutdown immune responses depending on the type and strength of the antigen encountered. Using mice deficient in both, Bim and Fas, it was convincingly shown that deletion of effector $T$ cells after an acute viral infection with HSV-1 was solely dependent on Bim, ${ }^{58}$ whereas shutdown of a chronic infection elicited by infection of these mice with mouse-herpes virus (MHV-68) was dependent on both Bim and Fas. ${ }^{58}$ This indicated different requirements of the intrinsic and extrinsic pathway for T-cell deletion, depending on acute versus chronic infections. The latter finding is consistent with the fact that auto-antigens can be considered as chronic and persistent antigens and in line with observations that re-stimulation of the TCR on activated T cells is required to drive expression of FasL triggering autocrine T-cell suicide or fratricide. ${ }^{2}$ It is noteworthy that another group studying clonal contraction of $\mathrm{T}$ cells after acute lymphocytic choriomeningitis virus (LCMV) infection also showed cooperation of Bim and Fas-mediated cell death, contrasting results using the HSV-1 model. ${ }^{59}$ However, one explanation for the noted difference may be that HSV-1 and LCMV epitopes provide different strength of signals to the reactive TCRs resulting in different activation levels of these effector molecules and types of immune responses. Consistent with these observations, Bim and Fas-deficiencies also cooperate in the induction of autoimmunity very early in age, accompanied by massive accumulation of leukocytes that can make up to half of the animal's body mass. Also unusual $\alpha \beta \mathrm{TCR}^{+} \mathrm{CD} 4^{-} \mathrm{CD}{ }^{-} \mathrm{B} 220^{+}$ $\mathrm{T}$ cells were observed on the pure $\mathrm{C} 57 \mathrm{BL} / 6$ background, in which normally neither loss of Bim nor Fas leads to pronounced autoimmune pathology. ${ }^{58}$ Thus, both the intrinsic as well as the extrinsic pathway are responsible for the elimination of effector $\mathrm{T}$ cells during the retraction phase of immune responses thereby preventing development of autoimmunity (Figure 3).

\section{Maintenance of Peripheral B-Cell Tolerance}

$B$ cells are also subjected to selection processes in the periphery on encounter of self-antigen. In the anti-HEL $\mathrm{Ig} /$ soluble (s)HEL autoimmune model, it has been shown that Bim levels are increased in BCR-transgenic B cells on encounter of the self-antigen ${ }^{60}$ and it has been suggested that the increased availability of BAFF (BlyS/TNFS13) on a per B-cell basis allows persistence of such auto-reactive cells in the double-transgenic mice that would otherwise die or are rapidly outcompeted by normal B cells. ${ }^{60}$ Consistently, Bimdeficiency or Bcl-2 overexpression rescues auto-reactive $B$ cells from deletion in the periphery of this model of negative B-cell selection. ${ }^{46}$ Furthermore, anergic $B$ cells in such antiHEL Ig/sHEL transgenic animals can become reactivated and secrete anti-HEL immunoglobulin if they lack Bim because 
they no longer depend on BAFF for survival but remain receptive for its differentiation signals. ${ }^{61}$ BAFF, produced mainly by innate immune cells and known to be critical for the survival of type 2 (T2) transitional and mature B cells, binds three receptors, $\mathrm{TACl}$ (transmembrane activator and calcium modulator and cyclophilin ligand interactor), BCMA (B-cell maturation antigen) and the BAFF-receptor (BAFF-R) (reviewed in Mackay and Schneider ${ }^{62}$ ). Signalling along the latter has been reported to counteract BCR ligation-induced accumulation of Bim and apoptosis in WEHI-231 cells, ${ }^{63}$ as well as a number of prosurvival molecules including $\mathrm{Bcl}-2$, $\mathrm{Bcl}-\mathrm{x}_{\mathrm{L}}$ and $\mathrm{Bfl}-1 / \mathrm{A} 1$, the latter most potently in conjunction with IL-17. ${ }^{14,62}$ All these prosurvival Bcl-2 family members potently block BCR-induced apoptosis in primary B cells or $B$-cell lines, but also cell death triggered by a number of other stimuli that are not mediated by Bim. Therefore, inhibition of Bim-accumulation on BCR-ligation may be only one aspect of (aberrant) B-cell survival inflicted by access BAFF, which may contribute to auto-immunity. BAFF transgenic mice show $B$-cell restricted hyperplasia affecting mainly $\mathrm{T} 2$ and mature marginal zone as well as follicular B cells. ${ }^{18,64}$ The arising autoimmunity in these mice resembles human SLE and Sjögrens syndrome and it was suggested that this might be due to increased survival of auto-reactive $B$ cells due a BAFFdriven increase in Bcl-2 protein levels. ${ }^{64}$ The B-cell phenotype of BAFF transgenic mice is similar to that observed in $E \mu-b c /-$ 2-22 transgenic mice, in which expression of the transgene was limited to the B-cell lineage, or bim ${ }^{-1-}$ mice, ${ }^{20,21}$ which highlights the connection between BAFF signalling and selection processes regulated by Bcl-2 family proteins.

An increased level of autoantibodies and the formation of immuncomplexes is a prominent feature of SLE in humans. Also Bim-deficient mice on a mixed 129SV-C57BL/6 background develop severe autoimmunity with SLE-like symptoms. Bim ${ }^{-1-}$ mice suffer from splenomegaly and lymphadenopathy resulting from two to four times increased numbers of lymphoid cells. In old mice the amount of IgG-secreting B cells was 200-fold augmented accompanied by a 10-fold increased level of IgG as well threefold of IgA and IgM. This suggests that Bim may become activated once the antigen has been cleared and survival factors become limiting for Ig-producing plasma cells or on ligation of $\mathrm{Fc} \gamma \mathrm{R}$ Ilb receptors, an inhibitory Fc-receptor expressed on the cell surface of $B$ cells. ${ }^{65}$ It is noteworthy that the number of lowaffinity Ig-expressing memory B cells was augmented in bim $^{-1-}$ mice indicating an important role of Bim in the elimination of low-affinity lg-bearing $B$ lymphocytes during germinal center reactions. ${ }^{66} \mathrm{~A}$ similar phenotype was observed in $\mathrm{Bcl}-2$ overexpressing mice but there the amount of serum Ig levels and the number of antigen-specific $B$ cells was even more increased, ${ }^{66}$ suggesting a possible contribution of other $\mathrm{BH}$ 3-only proteins, possibly Bmf or Puma. It is noteworthy that bim $^{-1-}$ puma $^{-1-}$ mice show a selective increase in IgA plasma levels that is comparable to the one observed in vav-bcl-2 transgenic mice implicating Puma in the survival of classswitched long-lived IgA-secreting plasma cells. ${ }^{49}$

In spite of the documented relevance of the intrinsic apoptosis pathway for the deletion of peripheral B cells it remains fact that $B$ cells are susceptible to Fas-induced killing. This death is most effectively blocked when BCR and CD40 become activated simultaneously, leading to enhanced expression of c-FLIP through NF-kB signalling, for example, in germinal center $B$ cells during affinity maturation. ${ }^{67,68}$ There, only B-cell clones with highest affinity for the antigen do survive while others die by neglect. Deletion of sub-optimal $B$-cell clones that do not receive a sufficiently strong survival signal through their BCR and CD40 molecules also involves Fas-mediated killing through $\mathrm{CD}^{+}{ }^{+}$intra-follicular helper T cells expressing FasL. ${ }^{69}$ One can envision a scenario in which insufficient BCR-signalling because of low-affinity antigen-recognition may lead to a drop in expression levels of pro-survival molecules such as Bcl-2 or Bfl-1/A1, sensitizing to BH3-only protein-regulated cell death while lack of CD40-ligation renders these cells susceptible to Fas-ligation, because of lack of NF-kB signalling culminating in low-level expression of c-FLIP. Why both mechanisms may be activated or are required to secure deletion of low-affinity B-cell clones remains unclear at present, but, as in T cells, this may depend on the type of antigen encountered. ${ }^{70}$ Consistently, experiments assessing the deletion of auto-reactive $B$ cells that may arise in germinal centers, for example, during receptor editing, again support the notion that both pathways are critical for the elimination of such cells. ${ }^{69}$

In summary, while the contribution of the extrinsic pathway for the establishment of central tolerance remains controversial, both the extrinsic Fas/FasL and the intrinsic Bcl-2regulated apoptosis are clearly pivotal for the maintenance of peripheral T- and B-cell tolerance. This notion is also supported by the vast and aggressive autoimmunity observed in bim $^{-1-}$ Ipr mice. ${ }^{13,58,59}$ Bim seems the key player in this event and so far little experimental evidence exists that other members of the $\mathrm{BH} 3$-only subgroup, although clearly coregulating lymphocyte homeostasis together with Bim, ${ }^{49,50}$ are critical for the maintenance of peripheral tolerance.

\section{Cell Death of APCs is Critical to Preclude Autoimmunity}

In spite of the massive lymphadenopathy and documented defects in activated T-cell apoptosis in Bim-deficient Ipr mice, it remains uncertain which cell type is the most critical determinant triggering exacerbated autoimmunity in these mice. Elegant studies using cell type restricted deletion of the Fas gene clearly showed that loss of Fas on DCs, which induce expression of this DR on exposure to microbial stimuli, is sufficient to cause systemic autoimmunity in mice. ${ }^{71}$ Hence, apoptosis of mature DCs by FasL-expressing activated antigenic $T$ cells restricts their lifespan and thereby limits the duration of an immune response through a negative regulatory loop. Similarly, deletion of Fas in B cells causes autoimmunity, presumably because Fas-sensitive antigenpresenting $B$ cells persist and sustain survival of self-reactive T cells that are usually deleted in a Fas-dependent manner. ${ }^{71}$ In contrast, it is still unclear which cell type is most critical for establishing autoimmunity in Bim-deficient animals on the mixed genetic background ${ }^{20}$ and cell type-specific deletion of bim may reveal interesting novel insights. However, one can assume that Bim, targeted by TLR-signalling in APCs, prevents autoimmunity also by limiting the lifespan of DCs. Bim-deficient DCs show reduced apoptosis and allow more sustained T-cell responses in vitro and in vivo. Furthermore, 
adoptive transfer of Bim-deficient DCs seems sufficient to induce auto-antibody production in recipient mice on challenge with LPS. ${ }^{72}$ Hence, it will be interesting to determine at which cellular level, Bim and Fas exert highest levels of synergy to preclude autoimmunity by combining conditional knockout models available for both genes.

\section{Effect of Cell Death on Treg Cell Homeostasis and Function}

Next to the induction of apoptosis and anergy, Treg cells are the key-regulators of peripheral tolerance. ${ }^{73}$ Treg cells arise in the thymus (natural Treg cells) and are characterized by the expression of cell surface markers such as CD4, the IL-2 receptor $\alpha$-chain, CD25, the TNF-R family members CD134 and GITR and the cytotoxic T-lymphocyte antigen-4 (CTLA-4). ${ }^{74}$ As these molecules can also be found on other cells only the transcription factor FoxP3 serves as reliable marker for Treg cells. ${ }^{75,76}$ In the absence of FoxP3 mice develop the scurfy phenotype and humans suffer from IPEX (immunodysregulation, polyendocrinopathy, enteropathy, X-linked) that is characterized by an ALPS and infiltration of multiple organs by activated CD4 ${ }^{+} \mathrm{T}_{\text {cells. }}{ }^{77}$ Furthermore, many autoimmune disorders are associated with a reduced function or decreased survival of Treg cells. ${ }^{78,79}$ Consistently, timed deletion of Treg cells causes severe autoimmunity in mice. ${ }^{80}$ Thus, the survival capacity of Treg cells and factors that affect on it are critical for the prevention of autoimmunity. However, mechanisms that control Treg survival remain controversial and poorly understood (Figure 4).

\section{Apoptosis as a Regulator of Treg Cell Maturation and Function}

Contrary to conventional CD4 ${ }^{+}$FoxP3 $^{-}$T cells, Treg cells are unable to produce IL-2 by themselves because FoxP3 impairs $I L 2$ transcription. Although Treg viability can be increased by other cytokines signalling through receptors containing the common (c) chain (e.g., IL-7, IL-15, IL-21), IL-2 is the most potent and represents their key survival factor. ${ }^{81}$ Although the development and function of Treg cells in IL-2- and CD25deficient mice is not impaired, their number in the periphery is strongly reduced leading to ALPS, as observed in scurfy mice. ${ }^{82}$ Furthermore, in murine autoimmune disease models the Treg: Teffector cell ratio was reduced because of IL-2deprivation and in a diabetes mouse model this resulted in a diminished expression of $\mathrm{Bcl}-2$ in Treg cells, indicative for increased apoptosis susceptibility. ${ }^{83}$ The BH3-only proteins Bim and Puma determine the sensitivity of $T$ cells to cytokine withdrawal-induced cell death by neutralizing $\mathrm{Bcl}-2$ and $\mathrm{Mcl}-$ 1. ${ }^{55,57}$ Consistently, T cells from Bim-deficient animals or mice overexpressing $\mathrm{Bcl}-2$ are more resistant to cytokine-deprivation and we noted that in these animals the percentage of Treg cells, in particular of the CD4 ${ }^{+} \mathrm{CD}_{2} 5^{-}$subset, is significantly increased. Although Puma can contribute to apoptosis induced by IL-2-deprivation in T cells ${ }^{55,57}$ and the elimination of antigen-activated T cells after acute viral infection, ${ }^{84}$ Treg cell numbers seem normal in puma ${ }^{-1-}$ mice (AV and DT, unpublished).

Increased Bcl-2 expression levels may also account for the reported resistance of Treg cells to glucocorticoids (GCs) when compared with conventional CD4 ${ }^{+} \mathrm{T}$ cells, ${ }^{85}$ maybe by buffering GC-mediated induction of Bim and Bmf, as observed in leukemia cells, ${ }^{86}$ or Puma, as noted in mouse thymocytes. $^{87}$ It is noteworthy that multiple sclerosis and SLE patients are commonly treated with GCs and in these patients an accumulation of Treg cells was observed on GC-therapy. ${ }^{88}$ In contrast, Treg cells are more susceptible to $\gamma$-irradiation ${ }^{89}$ and cyclophosphamide-mediated cytotoxicity, ${ }^{90}$ the latter may account for the accelerating effect of this drug on the development of type I diabetes in animal models. Apoptosis induced by $\gamma$-irradiation or DNA-damaging drugs in lymphocytes is mainly mediated by $\mathrm{Puma}^{87}$ and it will be interesting to see if Treg cells show stronger induction of Puma on DNA damage when compared with conventional T cells. In contrast, to naïve conventional $\mathrm{CD}^{+}{ }^{+} \mathrm{T}$ cells, Treg cells are highly susceptible to FasL-mediated cell death that may be explained by higher expression levels of Fas on their surface. ${ }^{91}$ Consistent with a role for the Fas/FasL system in Treg cell homeostasis, their number seems increased in FasL-deficient gldmice, ${ }^{92}$ an observation actually at odds with the observed autoimmunity in these animals, but one study also reported inefficient Treg cell activation by APCs in $M R L / l p r$ mice that may explain this discrepancy. ${ }^{93}$

\section{Apoptosis as a Means for Treg cells to Suppress Effector Cells}

Next to Treg cell homeostasis, survival factors also affect on Treg cell-mediated suppression of immune responses. Treg cells suppress other leukoytes by different mechanisms: This includes inhibition of dendritic cells by CTLA-4, the secretion

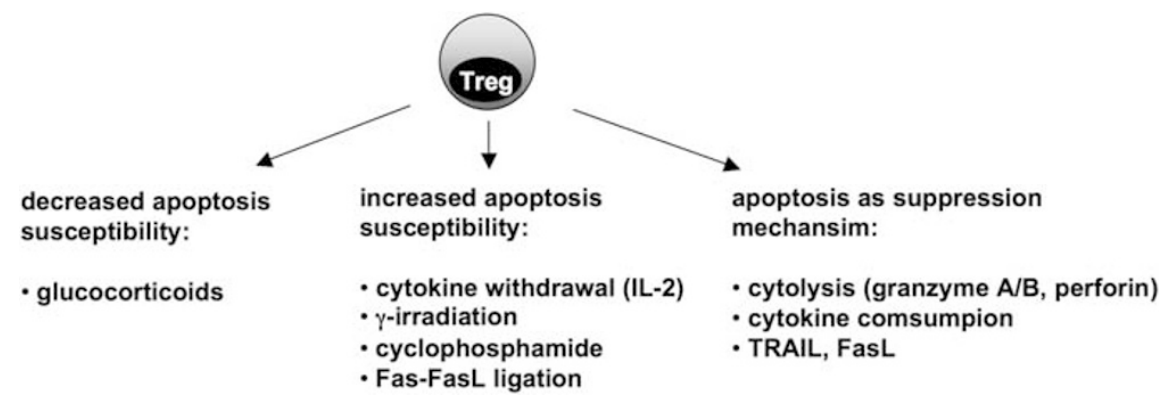

Figure 4 Apoptosis and Treg cell homeostasis and function. Apoptosis affects on Treg cell survival and function at multiple levels. Treg cell apoptosis susceptibility in response to GCs is decreased but increased in response to cytokine withdrawal, $\gamma$-irradiation, cyclophosphamide and Fas-FasL interaction, when compared with conventional CD4 T cells. In addition, Treg cells mediate their suppression of immune responses in part by induction of apoptosis (cytolysis, cytokine consumption or expression of DR-ligands) 
of anti-inflammmatory cytokines (IL-10, TGF- $\beta$, IL-35) or metabolic disruption of other leukocytes, for example, by transfer of inhibitory cAMP through gap junctions. ${ }^{94}$ However, also the induction of apoptosis in effector cells by the release of granzymes ${ }^{95}$ or expression of death ligands, for example, FasL or TRAIL, belongs to the key mechanisms used by Treg cells to mediate suppression. ${ }^{96-98}$ As mentioned above, Treg cells are unable to produce IL-2 by themselves but rely on this cytokine for survival. Hence, IL-2 consumption has been suggested as a means used by Treg cells to kill effector T cells during later stages of their activation. ${ }^{99}$ This model was supported by the observation that Bim-deficient $\mathrm{CD} 4^{+} \mathrm{T}$ cells were less susceptible to Treg cell induced apoptosis and wildtype responder cells showed reduced levels of phosphorylated Akt and the inactive phopho-form of the $\mathrm{BH}$-only protein Bad when co-cultured with Treg cells. ${ }^{99}$ However, another study using human Treg cells suggested that IL-2 depletion alone was not sufficient to suppress effector T cells. ${ }^{100}$ Hence, a more detailed analysis of the role of $\mathrm{Bcl}-2$ family proteins in Treg cell function seems warranted to resolve these issues.

\section{Targeting the Bcl-2-Regulated Apoptosis Pathway for Autoimmune Therapy}

In summary, Bcl-2 family proteins are most critical for the establishment and the maintenance of self-tolerance. Pro-inflammatory cytokines such as IL- 6 or IL-17 as well as critical B-cell survival factors such as BAFF, when produced in excess, can contribute to loss of tolerance and autoimmunity, in part by raising levels of pro-survival Bcl-2 family members or, alternatively, by reducing the levels or function of $\mathrm{BH} 3$-only proteins in effector cells, leading to a breach of tolerance. Hence, it seems feasible that the use of BH3-mimetics, compounds that mimic the action of $\mathrm{BH} 3-o n l y$ proteins, designed to overcome deregulations of the $\mathrm{Bcl}-2$ rheostat for the treatment of cancer, may become also a useful tool for the treatment of autoimmune disorders. Studies using animal models of collagen-induced arthritis and IFN- $\alpha$-induced lupus nephritis actually already provide prove of concept. Treatment of mice with the BH3-mimetic ABT-737 clearly delayed onset and severity of these induced autoimmune disorders, presumably by limiting antigen-specific lymphocyte survival and proliferation. ${ }^{101}$ Why antigen-activated or mitogen-treated cycling lymphocytes are more susceptible to ABT-737 than resting ones remains to be clarified. In addition, a recent study provided evidence that delivery of a cell-permeable Bim-BH3domain peptide effectively ameliorated autoimmune symptoms in an experimental arthritis model in mice by inducing apoptosis of myeloid cells in the joints of challenged animals, ${ }^{102}$ again suggesting that $\mathrm{BH} 3$-mimetics may become useful tools to treat autoimmune disorders. Hence, it will be interesting to see if and how BH3-mimetics improve the efficacy of drugs currently used to treat autoimmune symptoms.

\section{Conflict of interest}

The authors declare no conflict of interest.
Acknowledgements. We want to thank all our lab-members for insight-full discussion. The work in our laboratory is supported by grants from the Austrian Science Fund (SFB021 and the post-graduate program MCBO), the EU-FP6 frame work program (RTN-ApopTrain), the 'Krebshife-Tirol' and the IFTZ-program, sponsored by the Innsbruck Medical University.

1. Degterev A, Yuan J. Expansion and evolution of cell death programmes. Nat Rev Mol Cell Biol 2008; 9: 378-390.

2. Krammer PH. CD95's deadly mission in the immune system. Nature 2000; 407: 789-795.

3. Strasser A, Jost PJ, Nagata S. The many roles of FAS receptor signaling in the immune system. Immunity 2009; 30: 180-192.

4. Watanabe-Fukunaga $\mathrm{R}$, Brannan $\mathrm{Cl}$, Copeland NG, Jenkins NA, Nagata S. Lymphoproliferation disorder in mice explained by defects in Fas antigen that mediates apoptosis. Nature 1992; 356: 314-317.

5. Takahashi T, Tanaka M, Brannan Cl, Jenkins NA, Copeland NG, Suda T et al. Generalized lymphoproliferative disease in mice, caused by a point mutation in the Fas ligand. Cell 1994; 76: 969-976.

6. Rieux-Laucat F, Le Deist F, Fischer A. Autoimmune lymphoproliferative syndromes: genetic defects of apoptosis pathways. Cell Death Diff 2003; 10: 124-133.

7. Strasser A. The role of BH3-only proteins in the immune system. Nat Rev Immunol 2005; $\mathbf{5}$ : 189-200.

8. Zong WX, Lindsten T, Ross AJ, MacGregor GR, Thompson CB. BH3-only proteins that bind pro-survival $\mathrm{Bcl}-2$ family members fail to induce apoptosis in the absence of Bax and Bak. Genes Dev 2001; 15: 1481-1486.

9. Youle RJ, Strasser A. The BCL-2 protein family: opposing activities that mediate cell death. Nat Rev Mol Cell Biol 2008; 9: 47-59.

10. Chipuk JE, Green DR. How do BCL-2 proteins induce mitochondrial outer membrane permeabilization? Trends Cell Biol 2008; 18: 157-164

11. Nagata S, Hanayama R, Kawane K. Autoimmunity and the clearance of dead cells. Cell 2010; 140: 619-630.

12. Mehrian R, Quismorio Jr FP, Strassmann G, Stimmler MM, Horwitz DA, Kitridou RC et al. Synergistic effect between IL-10 and bcl-2 genotypes in determining susceptibility to systemic lupus erythematosus. Arthritis Rheum 1998; 41: 596-602.

13. Hutcheson J, Scatizzi JC, Siddiqui AM, Haines III GK, Wu T, Li QZ et al. Combined deficiency of proapoptotic regulators Bim and Fas results in the early onset of systemic autoimmunity. Immunity 2008; 28: 206-217.

14. Doreau A, Belot A, Bastid J, Riche B, Trescol-Biemont MC, Ranchin B et al. Interleukin 17 acts in synergy with B cell-activating factor to influence B cell biology and the pathophysiology of systemic lupus erythematosus. Nat Immunol 2009; 10: 778-785.

15. Andre J, Cimaz R, Ranchin B, Galambrun C, Bertrand Y, Bouvier R et al. Overexpression of the antiapoptotic gene Bfl-1 in B cells from patients with familial systemic lupus erythematosus. Lupus 2007; 16: 95-100.

16. Johansson C, Castillejo-Lopez C, Johanneson B, Svenungsson E, Gunnarsson I, Frostegard $\mathrm{J}$ et al. Association analysis with microsatellite and SNP markers does not support the involvement of BCL-2 in systemic lupus erythematosus in Mexican and Swedish patients and their families. Genes Immun 2000; 1: 380-385.

17. Oliveira JB, Bidere N, Niemela JE, Zheng L, Sakai K, Nix CP et al. NRAS mutation causes a human autoimmune lymphoproliferative syndrome. Proc Natl Acad Sci USA 2007; 104: 8953-8958.

18. Batten M, Groom J, Cachero TG, Qian F, Schneider P, Tschopp J et al. BAFF mediates survival of peripheral immature B lymphocytes. J Exp Med 2000; 192: 1453-1466.

19. Liston A, Lesage S, Gray DH, O'Reilly LA, Strasser A, Fahrer AM et al. Generalized resistance to thymic deletion in the NOD mouse; a polygenic trait characterized by defective induction of Bim. Immunity 2004; 21: 817-830.

20. Bouillet $P$, Metcalf D, Huang DCS, Tarlinton DM, Kay TWH, Köntgen F et al. Proapoptotic $\mathrm{Bcl}-2$ relative Bim required for certain apoptotic responses, leukocyte homeostasis, and to preclude autoimmunity. Science (New York, NY) 1999; 286: 1735-1738.

21. Strasser A, Whittingham S, Vaux DL, Bath ML, Adams JM, Cory S et al. Enforced BCL2 expression in B-lymphoid cells prolongs antibody responses and elicits autoimmune disease. Proc Natl Acad Sci USA 1991; 88: 8661-8665.

22. Egle A, Harris AW, Bath ML, O'Reilly L, Cory S. VavP-Bcl2 transgenic mice develop follicular lymphoma preceded by germinal center hyperplasia. Blood 2004; 103: 2276-2283.

23. Strasser A, Harris AW, Cory S. Bcl-2 transgene inhibits T cell death and perturbs thymic self-censorship. Cell 1991; 67: 889-899.

24. Rathmell JC, Lindsten T, Zong WX, Cinalli RM, Thompson CB. Deficiency in Bak and Bax perturbs thymic selection and lymphoid homeostasis. Nat Immunol 2002; 3: 932-939.

25. Bouillet $\mathrm{P}$, Purton JF, Godfrey DI, Zhang L-C, Coultas L, Puthalakath $\mathrm{H}$ et al. BH3-only $\mathrm{Bcl}-2$ family member $\mathrm{Bim}$ is required for apoptosis of autoreactive thymocytes. Nature 2002; 415: 922-926.

26. Villunger A, Marsden VS, Zhan Y, Erlacher M, Lew AM, Bouillet $P$ et al. Negative selection of semimature $\mathrm{CD} 4(+) 8(-) \mathrm{HSA}+$ thymocytes requires the $\mathrm{BH} 3-$ only protein Bim but is independent of death receptor signaling. Proc Natl Acad Sci USA 2004; 101: 7052-7057. 
27. Cretney E, Uldrich AP, Berzins SP, Strasser A, Godfrey DI, Smyth MJ. Normal thymocyte negative selection in TRAIL-deficient mice. J Exp Med 2003; 198: 491-496.

28. Lamhamedi-Cherradi SE, Zheng SJ, Maguschak KA, Peschon J, Chen YH. Defective thymocyte apoptosis and accelerated autoimmune diseases in TRAIL-/- mice. Nat Immunol 2003; 4: 255-260.

29. Cretney E, Uldrich AP, McNab FW, Godfrey DI, Smyth MJ. No requirement for TRAIL in intrathymic negative selection. Int Immunol 2008; 20: 267-276.

30. Bouillet P, Cory S, Zhang L-C, Strasser A, Adams JM. Degenerative disorders caused by Bcl-2 deficiency are prevented by loss of its BH3-only antagonist Bim. Dev Cell 2001; 1: 645-653.

31. Ludwinski MW, Sun J, Hilliard B, Gong S, Xue F, Carmody RJ et al. Critical roles of Bim in $T$ cell activation and $T$ cell-mediated autoimmune inflammation in mice. J Clin Invest 2009; 119: 1706-1713.

32. Rong Y, Distelhorst CW. Bcl-2 protein family members: versatile regulators of calcium signaling in cell survival and apoptosis. Annu Rev Physiol 2008; 70: 73-91.

33. Hu Q, Sader A, Parkman JC, Baldwin TA. Bim-mediated apoptosis is not necessary for thymic negative selection to ubiquitous self-antigens. J Immunol 2009; 183: 7761-7767.

34. Jorgensen TN, McKee A, Wang M, Kushnir E, White J, Refaeli Y et al. Bim and Bcl-2 mutually affect the expression of the other in T cells. J Immunol 2007; 179: 3417-3424.

35. Kovalovsky D, Pezzano M, Ortiz BD, Sant'Angelo DB. A novel TCR transgenic model reveals that negative selection involves an immediate, Bim-dependent pathway and a delayed, Bim-independent pathway. PLoS One 2010; 5: e8675.

36. Sohn SJ, Thompson J, Winoto A. Apoptosis during negative selection of autoreactive thymocytes. Curr Opin Immunol 2007; 19: 510-515.

37. Lin B, Kolluri SK, Lin F, Liu W, Han YH, Cao X et al. Conversion of Bcl-2 from protector to killer by interaction with nuclear orphan receptor Nur77/TR3. Cell 2004; 116: 527-540.

38. Thompson J, Winoto A. During negative selection, Nur77 family proteins translocate to mitochondria where they associate with $\mathrm{Bcl}-2$ and expose its proapoptotic $\mathrm{BH} 3$ domain. $J$ Exp Med 2008; 205: 1029-1036.

39. Wojciechowski S, Tripathi P, Bourdeau T, Acero L, Grimes HL, Katz JD et al. Bim/Bcl-2 balance is critical for maintaining naive and memory T cell homeostasis. J Exp Med 2007; 204: 1665-1675.

40. Rajpal A, Cho YA, Yelent B, Koza-Taylor PH, Li D, Chen E et al. Transcriptional activation of known and novel apoptotic pathways by Nur77 orphan steroid receptor. EMBOJ 2003; 22: $6526-6536$

41. Kuang $A A$, Cado $D$, Winoto $A$. Nur77 transcription activity correlates with its apoptotic function in vivo. Eur J Immunol 1999; 29: 3722-3728.

42. von Boehmer $\mathrm{H}$, Melchers $\mathrm{F}$. Checkpoints in lymphocyte development and autoimmune disease. Nat Immunol 2010; 11: 14-20.

43. Wiesner DA, Kilkus JP, Gottschalk AR, Quintáns J, Dawson G. Anti-immunoglobulininduced apoptosis in WEHI 231 cells involves the slow formation of ceramide from sphingomyelin and is blocked by bcl- $\mathrm{x}_{\mathrm{L}}$. J Biol Chem 1997; 272: 9868-9876.

44. Kuss AW, Knödel M, Berberich-Siebelt $F$, Lindemann D, Schimpl A, Berberich I. A expression is stimulated by CD40 in B cells and rescues WEHI 231 cells from anti-IgMinduced cell death. Eur J Immunol 1999; 29: 3077-3088.

45. Wen R, Chen Y, Xue L, Schuman J, Yang S, Morris SW et al. Phospholipase Cgamma2 provides survival signals via $B c l 2$ and $A 1$ in different subpopulations of $B$ cells. J Biol Chem 2003; 278: 43654-43662.

46. Enders A, Bouillet $\mathrm{P}$, Puthalakath $\mathrm{H}, \mathrm{Xu} \mathrm{Y}$, Tarlinton DM, Strasser A. Loss of the proapoptotic BH3-only Bcl-2 family member Bim inhibits BCR stimulation-induced apoptosis and deletion of autoreactive B cells. J Exp Med 2003; 198: 1119-1126.

47. Labi V, Erlacher M, Kiessling S, Manzl C, Frenzel A, O'Reilly L et al. Loss of the BH3-only protein Bmf impairs $B$ cell homeostasis and accelerates gamma irradiation-induced thymic lymphoma development. J Exp Med 2008; 205: 641-655.

48. Takeuchi O, Fisher J, Suh H, Harada H, Malynn BA, Korsmeyer SJ. Essential role of BAX, BAK in B cell homeostasis and prevention of autoimmune disease. Proc Natl Acad Sci USA 2005; 102: 11272-11277.

49. Erlacher M, Labi V, Manzl C, Bock G, Tzankov A, Hacker G et al. Puma cooperates with $\mathrm{Bim}$, the rate-limiting $\mathrm{BH} 3$-only protein in cell death during lymphocyte development, in apoptosis induction. J Exp Med 2006; 203: 2939-2951.

50. Hubner A, Cavanagh-Kyros J, Rincon M, Flavell RA, Davis RJ. Functional cooperation of the proapoptotic Bcl2 family proteins Bmf and Bim in vivo. Mol Cell Biol 2010; 30: 98-105.

51. Davey GM, Kurts C, Miller JF, Bouillet P, Strasser A, Brooks AG et al. Peripheral deletion of autoreactive CD8 $\mathrm{T}$ cells by cross presentation of self-antigen occurs by a Bcl-2inhibitable pathway mediated by Bim. J Exp Med 2002; 196: 947-955.

52. Barron L, Knoechel B, Lohr J, Abbas AK. Cutting edge: contributions of apoptosis and anergy to systemic T cell tolerance. J Immunol 2008; 180: 2762-2766.

53. Pellegrini M, Belz G, Bouillet $P$, Strasser $A$. Shutdown of an acute $T$ cell immune response to viral infection is mediated by the proapoptotic Bcl-2 homology 3-only protein Bim. Proc Natl Acad Sci USA 2003; 100: 14175-14180.

54. Hildeman DA, Zhu Y, Mitchell TC, Bouillet P, Strasser A, Kappler J et al. Activated T cell death in vivo mediated by pro-apoptotic Bcl-2 family member, Bim. Immunity 2002; 16 759-767.

55. Bauer A, Villunger A, Labi V, Fischer SF, Strasser A, Wagner H et al. The NF-\{kappa\}B regulator Bcl-3 and the $\mathrm{BH} 3$-only proteins Bim and Puma control the death of activated T cells. Proc Natl Acad Sci USA 2006; 103: 10979-10984.
56. Strasser A, Harris AW, Huang DCS, Krammer PH, Cory S. Bcl-2 and Fas/APO-1 regulate distinct pathways to lymphocyte apoptosis. EMBOJ 1995; 14: 6136-6147.

57. You H, Pellegrini M, Tsuchihara K, Yamamoto K, Hacker G, Erlacher M et al. FOXO3adependent regulation of Puma in response to cytokine/growth factor withdrawal. $J$ Exp Med 2006; 203: 1657-1663.

58. Hughes PD, Belz GT, Fortner KA, Budd RC, Strasser A, Bouillet P. Apoptosis regulators Fas and Bim cooperate in shutdown of chronic immune responses and prevention of autoimmunity. Immunity 2008; 28: 197-205.

59. Weant AE, Michalek RD, Khan IU, Holbrook BC, Willingham MC, Grayson JM. Apoptosis regulators Bim and Fas function concurrently to control autoimmunity and CD8+ T cell contraction. Immunity 2008; 28: 218-230.

60. Lesley $R, X u Y$, Kalled SL, Hess DM, Schwab SR, Shu HB et al. Reduced competitiveness of autoantigen-engaged $B$ cells due to increased dependence on BAFF. Immunity 2004; 20: 441-453.

61. Oliver PM, Vass T, Kappler J, Marrack P. Loss of the proapoptotic protein, Bim, breaks B cell anergy. J Exp Med 2006; 203: 731-741.

62. Mackay F, Schneider P. Cracking the BAFF code. Nat Rev Immunol 2009; 9: 491-502.

63. Craxton A, Draves KE, Gruppi A, Clark EA. BAFF regulates B cell survival by downregulating the BH3-only family member Bim via the ERK pathway. J Exp Med 2005; 202: 1363-1374.

64. Mackay F, Woodcock SA, Lawton P, Ambrose C, Baetscher M, Schneider P et al. Mice transgenic for BAFF develop lymphocytic disorders along with autoimmune manifestations. J Exp Med 1999; 190: 1697-1710.

65. Xiang Z, Cutler AJ, Brownlie RJ, Fairfax K, Lawlor KE, Severinson E et al. FcgammaRllb controls bone marrow plasma cell persistence and apoptosis. Nat Immunol 2007; 8: 419-429.

66. Fischer SF, Bouillet P, O'Donnell K, Light A, Tarlinton DM, Strasser A. Proapoptotic BH3 only protein Bim is essential for developmentally programmed death of germinal centerderived memory B cells and antibody-forming cells. Blood 2007; 110: 3978-3984.

67. Rothstein TL, Wang JKM, Panka DJ, Foote LC, Wang Z, Stanger B et al. Protection against Fas-dependent Th1-mediated apoptosis by antigen receptor engagement in $\mathrm{B}$ cells. Nature 1995; 374: 163-165.

68. Hennino A, Bérard M, Krammer PH, Defrance T. FLICE-inhibitory protein is a key regulator of germinal center B cell apoptosis. J Exp Med 2001; 193: 447-458.

69. Rathmell JC, Cooke MP, Ho WY, Grein J, Townsend SE, Davis MM et al. CD95 (Fas)dependent elimination of self-reactive B cells upon interaction with $\mathrm{CD}^{+} \mathrm{T}$ cells. Nature 1995; 376: 181-184.

70. Bouillet P, O'Reilly LA. CD95, BIM and T cell homeostasis. Nat Rev Immunol 2009; 9: 514-519.

71. Stranges PB, Watson J, Cooper CJ, Choisy-Rossi CM, Stonebraker AC, Beighton RA et al. Elimination of antigen-presenting cells and autoreactive T cells by Fas contributes to prevention of autoimmunity. Immunity 2007; 26: 629-641

72. Chen M, Huang L, Wang J. Deficiency of Bim in dendritic cells contributes to overactivation of lymphocytes and autoimmunity. Blood 2007; 109: 4360-4367.

73. Vignali DA, Collison LW, Workman CJ. How regulatory T cells work. Nat Rev Immunol 2008; 8: 523-532

74. Wing K, Suri-Payer E, Rudin A. CD4+CD25+-regulatory T cells from mouse to man Scand J Immunol 2005; 62: 1-15

75. Williams LM, Rudensky AY. Maintenance of the Foxp3-dependent developmental program in mature regulatory $T$ cells requires continued expression of Foxp3. Nat Immunol 2007; 8: 277-284.

76. Fontenot JD, Rasmussen JP, Williams LM, Dooley JL, Farr AG, Rudensky AY. Regulatory T cell lineage specification by the forkhead transcription factor foxp3. Immunity 2005; 22: 329-341.

77. Gambineri E, Torgerson TR, Ochs HD. Immune dysregulation, polyendocrinopathy, enteropathy, and X-linked inheritance (IPEX), a syndrome of systemic autoimmunity caused by mutations of FOXP3, a critical regulator of T-cell homeostasis. Curr Opin Rheumatol 2003; 15: 430-435.

78. Huan J, Culbertson N, Spencer L, Bartholomew R, Burrows GG, Chou YK et al. Decreased FOXP3 levels in multiple sclerosis patients. J Neurosci Res 2005; 81: 45-52.

79. Kumar $\mathrm{M}$, Putzki N, Limmroth V, Remus R, Lindemann $\mathrm{M}$, Knop $\mathrm{D}$ et al. $\mathrm{CD} 4+\mathrm{CD} 25+\mathrm{FoxP} 3+\mathrm{T}$ lymphocytes fail to suppress myelin basic protein-induced proliferation in patients with multiple sclerosis. J Neuroimmunol 2006; 180: 178-184.

80. Lahl K, Loddenkemper C, Drouin C, Freyer J, Arnason J, Eberl G et al. Selective depletion of Foxp3+ regulatory T cells induces a scurfy-like disease. J Exp Med 2007; 204: 57-63.

81. Pandiyan $\mathrm{P}$, Lenardo MJ. The control of $\mathrm{CD} 4+\mathrm{CD} 25+\mathrm{Foxp} 3+$ regulatory $\mathrm{T}$ cell survival. Biol Direct 2008; 3: 6

82. Fontenot JD, Rasmussen JP, Gavin MA, Rudensky AY. A function for interleukin 2 in Foxp3-expressing regulatory T cells. Nat Immunol 2005; 6: 1142-1151.

83. Tang Q, Adams JY, Penaranda C, Melli K, Piaggio E, Sgouroudis E et al. Central role of defective interleukin-2 production in the triggering of islet autoimmune destruction. Immunity 2008; 28: 687-697.

84. Fischer SF, Belz GT, Strasser A. BH3-only protein Puma contributes to death of antigenspecific T cells during shutdown of an immune response to acute viral infection. Proc Natl Acad Sci USA 2008; 105: 3035-3040.

85. Chen X, Murakami T, Oppenheim JJ, Howard OM. Differential response of murine $\mathrm{CD} 4+\mathrm{CD} 25+$ and $\mathrm{CD} 4+\mathrm{CD} 25-\mathrm{T}$ cells to dexamethasone-induced cell death Eur J Immunol 2004; 34: 859-869. 
86. Ploner C, Rainer J, Niederegger H, Eduardoff M, Villunger A, Geley S et al. The BCL2 rheostat in glucocorticoid-induced apoptosis of acute lymphoblastic leukemia. Leukemia 2008; 22: 370-377.

87. Villunger A, Michalak EM, Coultas L, Mullauer F, Bock G, Ausserlechner MJ et al. p53and drug-induced apoptotic responses mediated by BH3-only proteins puma and noxa. Science (New York, NY) 2003; 302: 1036-1038.

88. Chen X, Oppenheim JJ, Winkler-Pickett RT, Ortaldo JR, Howard OM. Glucocorticoid amplifies IL-2-dependent expansion of functional FoxP3(+)CD4(+)CD25(+) T regulatory cells in vivo and enhances their capacity to suppress EAE. Eur J Immunol 2006; 36: 2139-2149.

89. Kipnis J, Avidan H, Markovich Y, Mizrahi T, Hauben E, Prigozhina TB et al. Low-dose gamma-irradiation promotes survival of injured neurons in the central nervous system via homeostasis-driven proliferation of T cells. Eur J Neurosci 2004; 19: 1191-1198.

90. Lutsiak ME, Semnani RT, De Pascalis R, Kashmiri SV, Schlom J, Sabzevari H. Inhibition of $\mathrm{CD} 4(+) 25+\mathrm{T}$ regulatory cell function implicated in enhanced immune response by lowdose cyclophosphamide. Blood 2005; 105: 2862-2868.

91. Fritzsching B, Oberle N, Eberhardt N, Quick S, Haas J, Wildemann B et al. In contrast to effector T cells, CD4+CD25+FoxP3+ regulatory T cells are highly susceptible to CD95 ligand- but not to TCR-mediated cell death. J Immunol 2005; 175: 32-36.

92. Mohamood AS, Trujillo CJ, Zheng D, Jie C, Murillo FM, Schneck JP et al. Gld mutation of Fas ligand increases the frequency and up-regulates cell survival genes in CD25+CD4+ TR cells. Int Immunol 2006; 18: 1265-1277.

93. Parietti V, Monneaux F, Decossas M, Muller S. Function of CD4+, CD25+ Treg cells in $\mathrm{MRL} / \mathrm{pr}$ mice is compromised by intrinsic defects in antigen-presenting cells and effector T cells. Arthritis Rheum 2008; 58: 1751-1761.

94. Wing K, Sakaguchi S. Regulatory T cells exert checks and balances on self tolerance and autoimmunity. Nat Immunol 2010; 11: 7-13.

95. Grossman WJ, Verbsky JW, Barchet W, Colonna M, Atkinson JP, Ley TJ. Human T regulatory cells can use the perforin pathway to cause autologous target cell death Immunity 2004; 21: 589-601.
96. Venet F, Pachot A, Debard AL, Bohe J, Bienvenu J, Lepape A et al. Human CD4+CD25+ regulatory $T$ lymphocytes inhibit lipopolysaccharide-induced monocyte survival through a Fas/Fas ligand-dependent mechanism. J Immunol 2006; 177: 6540-6547.

97. Strauss L, Bergmann C, Whiteside TL. Human circulating CD4+CD25highFoxp3+ regulatory $\mathrm{T}$ cells kill autologous $\mathrm{CD} 8+$ but not $\mathrm{CD} 4+$ responder cells by Fas-mediated apoptosis. J Immunol 2009; 182: 1469-1480.

98. Ren X, Ye F, Jiang Z, Chu Y, Xiong S, Wang Y. Involvement of cellular death in TRAIL/ DR5-dependent suppression induced by $\operatorname{CD} 4(+) \operatorname{CD} 25(+)$ regulatory T cells. Cell Death Diff 2007; 14: 2076-2084.

99. Pandiyan $\mathrm{P}$, Zheng $\mathrm{L}$, Ishihara $\mathrm{S}$, Reed J, Lenardo MJ. CD4+CD25+Foxp3+ regulatory $\mathrm{T}$ cells induce cytokine deprivation-mediated apoptosis of effector CD4+ $\mathrm{T}$ cells. Nat Immunol 2007; 8: 1353-1362.

100. Tran DQ, Glass DD, Uzel G, Darnell DA, Spalding C, Holland SM et al. Analysis of adhesion molecules, target cells, and role of IL-2 in human FOXP3+ regulatory $\mathrm{T}$ cell suppressor function. J Immunol 2009; 182: 2929-2938.

101. Bardwell PD, Gu J, McCarthy D, Wallace C, Bryant S, Goess C et al. The Bcl-2 family antagonist ABT-737 significantly inhibits multiple animal models of autoimmunity. $\mathrm{J}$ Immunol 2009; 182: 7482-7489.

102. Scatizzi JC, Hutcheson J, Pope RM, Firestein GS, Koch AE, Mavers M et al. Bim-Bcl-2 homology 3 mimetic therapy is effective at suppressing inflammatory arthritis through the activation of myeloid cell apoptosis. Arthritis Rheum 2010; 62: 441-451.

Cell Death and Disease is an open-access journal published by Nature Publishing Group. This work is licensed under a Creative Commons Attribution-Noncommercial-Share Alike 3.0 License. To view a copy of this license, visit http:// creativecommons.org/licenses/by-nc-sa/3.0/ 